\title{
4 \\ Making and Remaking the World of the Kasakh Valley
}

Two or three days' travel on horseback eastward from the medieval site of Ani, the Kasakh River Valley runs north to south, following the curve of the eastern flank of the broad volcanic cone of Mount Aragats. The eastern margin of the valley is defined by the sweep of the granitic Tsaghkunyats range, punctuated at its southern end by the smaller volcanic peak of Arai Ler (Mount Ara). Just south of the mountain shoulder occupied by the medieval sites of Uši, Hovhannavank', and Sałmosavank', the highland drops off sharply into the broad plain of the Araxes River: near the edge of the plateau the Kasakh River becomes deeply incised in a precipitous canyon, just north of Arai Ler. Its steady change in elevation from south to north makes the Kasakh Valley a climatic transition zone, with the lower reaches currently covered by dense fruit orchards and the northern extent transitioning to fodder and grain farming, as well as pasture, toward the town of Aparan. The flanks of Mount Aragats and the Tsaghkunyats are marked by remains of seasonal pastoralist campsites, from villagers and groups of Yezidi Kurds moving their flocks, herds, and horses (as well as trucks and campers) between the lower and upper slopes (see fig. 7).

In this chapter I will think at the scale of the Kasakh Valley, at the small world of fields, roads, rivers, and towns framed by mountain passes and peaks. This framing is somewhat arbitrary. During the twelfth to fourteenth centuries, the Kasakh was part of a much larger administrative territory, which incorporated towns and villages in Shirak to the west as well as Lori to the north. As the materials and texts discussed in this book repeatedly demonstrate, people in the valleys of Armenia also participated (with greater or lesser degrees of agency and awareness) in global cultures and worlds of desire and distinction. My decision to situate the "local" scales of this discussion in the span of a single river valley is, however, also rooted within longer, twentieth-century habits of categorization, of thinking about this 


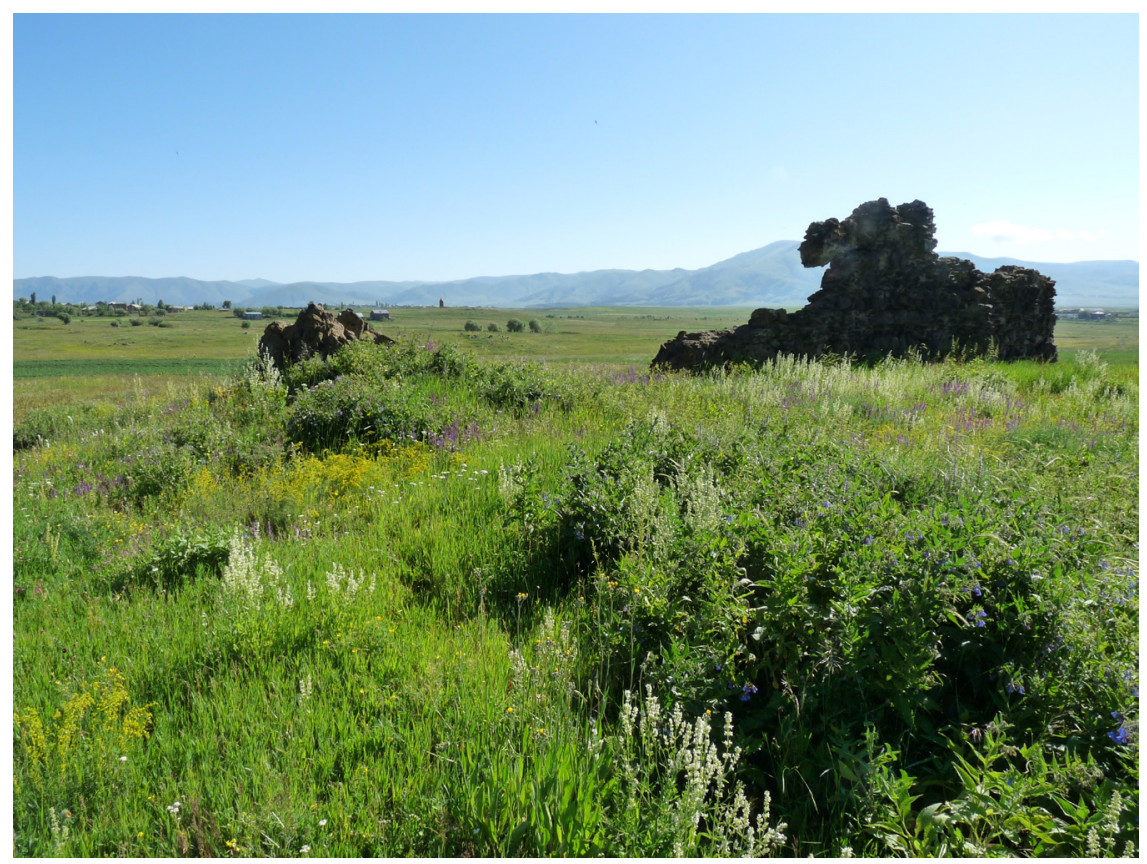

FIGURE 7. A view of the Kasakh Valley from among the ruins of the Arai-Bazarjuł caravanserai. Photo by the author.

place as a geographic unit, as a landscape. I want to think about the Kasakh Valley as a place constructed by the rhythms of medieval lives, and also by a century of geographical and archaeological practice in Soviet and modern Armenia. I will explore how the place that we call the Kasakh Valley was made with apparatuses of scientific knowledge, through storytelling, through writing of various kinds. One aim is to think about the intersections of landscape archaeology, cartography, and epigraphy as a way of bringing a medieval landscape into being. Another is to materialize the Kasakh Valley as a landscape constructed in the modern as well as medieval periods, as a participant in overlapping world-makings rather than as the setting or backdrop within or against which human beings carried out their projects. As discussed in chapter 1, cosmopolitanism as a universalizing Enlightenment virtue struggles to make space for difference, or to account for the ways that more ordinary people experience difference in their daily lives. My ultimate aim is to materialize the Kasakh as something more than the "local" to the Silk Road's "global," to think about the landscape that frames everyday lives, and the complex scales of memory, mobility, and imagination, as well as situated "views of the transcendent." This requires thinking about the Kasakh as a landscape in the way it has been envisioned and mattered as a scale of cultural imagining- 
as Barbara Bender's "time materializing,"2 or Kathleen Stewart's "proliferation of signs written tentatively or persistently." ${ }^{3}$ Methodologically, it requires framing the Kasakh Valley as a place made through intersecting projects of dwelling in the medieval period, and various techniques of research in the recent past and present.

Survey is the primary methodology associated with landscape archaeology, a branch of the discipline which engages past human practices at the scale of landscape-an amorphous category that voraciously incorporates environment, nature, space, architecture, infrastructure, ecology, and other frameworks for thinking about human physical and imaginary senses of place. ${ }^{4}$ My own orientation focuses on landscape archaeology's strengths with spacetime, for thinking about human life at complex and multiple spatiotemporal scales. Explicitly making scale a problem is important for attempting to think beyond the patterns of visible monumentality and architectural "authorship." Likewise, thinking in terms of nested and overlapping landscapes conceptually links all the places within this book: moving human and nonhuman bodies, monumental buildings, villages, imagined places, tangible and/or tasty materialities. On a practical level, survey encourages thinking about the past while literally in motion, driving and walking across changing topographies; though not all landscape archaeologists would admit it, published accounts of surveys record the artifacts of bodily experiences of landscape.

To write the Kasakh Valley as a landscape means not just to tell the history of this place, but to reflect on the ways that such a place has been rebuilt, renamed, razed, and reinhabited in material fact and in scientific knowledge-and how all of these versions of place are layered within any earnest history of the valley and the people dwelling in and with it. In the medieval period the Kasakh was part of a broader region referred to as the province of Nig, with the same name being applied to the town now called Aparan. The name of the town changed multiple times over the early modern period, until the 1930s when it was changed again from Kasał to Aparan. In a similar manner, the villages of the Kasakh valley (and indeed all Armenia) were renamed multiple times in the course of their history, usually with the last renaming occurring in the period after the dissolution of the Soviet Union. ${ }^{5}$ The landscape of Nig-Aparan was researched in terms of its archaeological and architectural features in the early part of the twentieth century by a team led by the architect and archaeologist T'oros T'oramanyan, while individual buildings were studied by multiple archaeologists and historians, and continued to make major contributions to the study of Armenian history and prehistory. ${ }^{6}$

The archaeological surveys led by T'oramanyan provided the foundation for a generation of publications and further research, not least by generating an archive of photographs of inscriptions, buildings and sites. ${ }^{7}$ T'oramanyan's Materials for Armenian Architectural History is a two-volume compendium; the first volume presents a general history of Armenian architecture, with a central focus on Ani and early medieval churches. For the present discussion I will focus on the second volume, which includes a brief but significant essay on the origins and development 


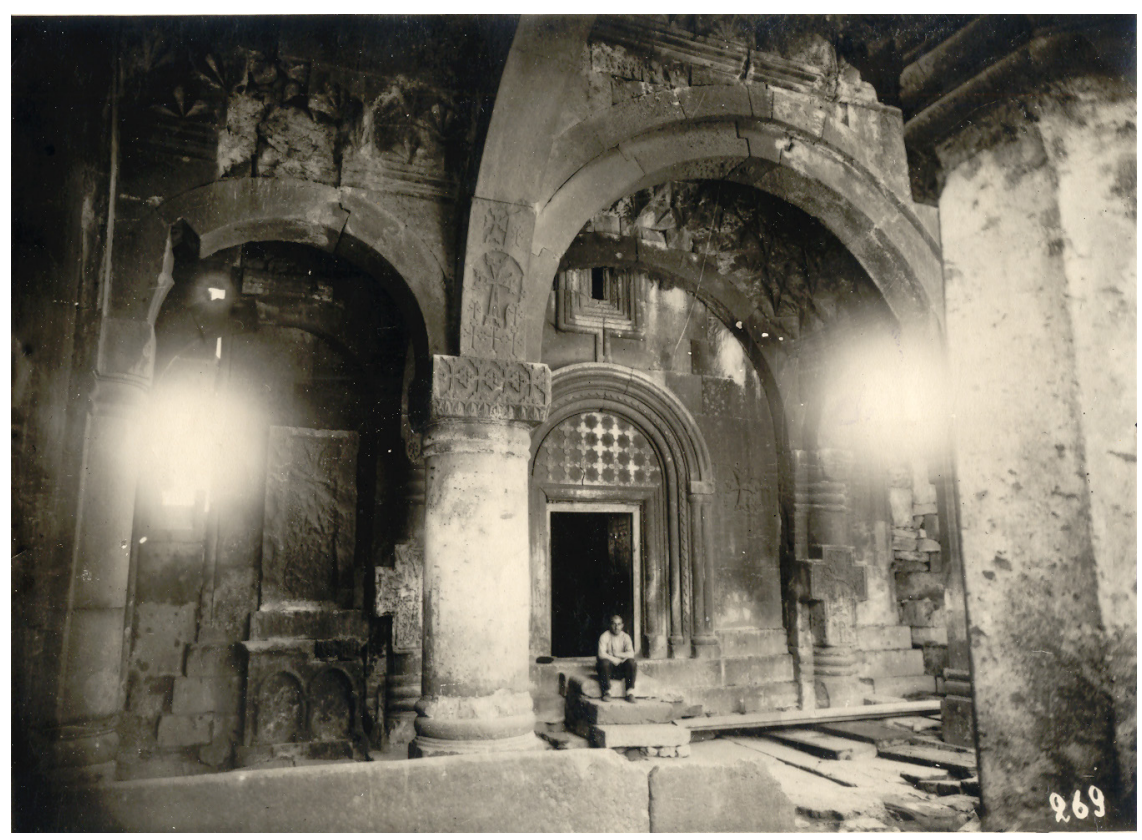

FIGURE 8. The gavit of Astvacnkal, facing the door into the main church. Note the muqarnas vaulting of the gavit. T'oromanyan archive: figure used with the permission of the Service for the Protection of Historical Environment and Cultural Museum-Reservations SNCO.

of Armenian architecture including the church form, ${ }^{8}$ in addition to a case-by-case discussion of Armenian monuments. The main part of this latter section takes the form of a survey of the country, divided into "travel notebooks" (čambordakan cogatetr). The fourth of these covers the trip "from Ejmiatsin toward the slopes of Aragats," containing a technical account of the standing medieval remains from village to village up this road, recorded in terms of their degree of preservation, with sketch plans of their architecture, and exemplary photographs (see fig. 8).

These images are themselves evocative records of the survey as part of a broader history of regime consolidation and the construction of a cultural past. The majority of the images are remarkable to a modern archaeological gaze, in that people are visible (archaeologists tend to crop people out of "scientific" images), standing in front of and upon the medieval buildings. A whole troupe of schoolchildren sits cross-legged and grinning within a ruined gavit at Marmašen $;{ }^{10}$ village men in cloaks and fleece hats perch atop the remains of the fifth-century basilica church in Aparan (called Kasał at that time). An image of the church at Tełer, endowed in 1232 by Mamaxatun Vačcutyan, shows two shadowy figures seated within the decorated doorway; one of them holds a sketchbook open on their lap. The T'oramanyan photos preserve a way of living with the medieval architectural past which is increasingly hard to find in Armenia, as a result of Soviet projects of 
renovation and monumentalization which transformed ruins into landmarks-as well as the revival of Christian practice in the last thirty years which has further brought medieval churches out of the ruined past and into contemporary use. In a broad shot of the church of Astvacnkal we see the ruined church and gavit (now collapsed) in the background, surrounded by a wall of fieldstones; in the foreground, greenery covers ruined walls. To the left of these, a woman peers away from us and waves around the corner of a house, her head in shadow; behind her, a small child is blurred by movement. Above the lintel of the house we can barely make out the trace of carved decoration, suggesting that the house (like many in Armenia) is constructed from medieval spolia. This house no longer exists: the population of Astvacnkal was removed to Yerevan in the 1950s, founding a neighborhood on the northern edge of the city called Kasax. ${ }^{11}$ Despite active projects of reconstruction, the T'oramanyan survey recorded traces of buildings which no longer stand, and which are especially visible in the clear original photo prints. One of these shows a man sitting on the steps leading from the gavit into the church at Astvacnkal (fig. 8); above him arches the original thirteenth century ceiling, now collapsed. But we can see in this photograph that the ceiling was configured in delicate muqarnas, or carved stone canopies formed from complex, interlocking geometrical shapes. ${ }^{12}$ T'oramanyan's text, like most archaeological survey reports, is a bound spacetime, containing spaces, landscapes, and ways of dwelling, frozen in the time of writing. The details T'oramanyan recorded are precious-for instance, T'oramanyan records a now lost inscription from the caravanserai south of Arai village, dating that building to the year 1213. Throughout my analysis I rely on this date provided by T'oramanyan, and I am aware that my own archaeological and historical world-making builds on this trace-within-a-trace, a landmark in a written world that is lost from the "real" landscape.

In 1988 V.M. Petrosyanc ' took up the task of compiling a total history of the ancient and medieval monuments in Nig-Aparan, for the first time "systematically organizing the history of Nig-Aparan on the basis of textual and epigraphic evidence." ${ }^{3}$ The introduction to Petrosyanc's work effectively demonstrates the issues of authorship, visibility, and historical agency that I discussed earlier. Successive rulers and political figures were assessed based on their ability to contribute to the "text" that Petrosyanc' was himself editing: the legible historical-architectural (patmačartarapetakan) landscape of the broader Kasakh region. Petrosyanc' began his history, predictably, with the first named subjects of history in the Kasakh: the Gntuni princely dynasty, which administered the territory from the first century till the tenth century, when they were noted among the vassal princes of the Bagratuni. From the mid-tenth through the late twelfth centuries Nig-Aparan was under the control of a succession of Turkic groups; first the Sheddadids and Delmiks (a group from what is now Iran), followed by the eleventh-century Seljuk conquest. Interestingly, Petrosyanc' dismisses this period, saying of the Pahlavuni and their followers: "unlike the Gntuni, during the near century of their reign[s], 
they did not undertake a single architectural construction." ${ }^{14}$ From the perspective of Petrosyanc's late-twentieth-century archaeology, the presence of these groups in the Kasakh Valley was disciplinarily invisible. This pattern was, of course, completely reversed after the Zak'arid conquest of the valley in the late twelfth century, and the installation of the Vačutyans in the early years of the thirteenth.

The Vačutyans were among the largest and most influential of the Armenian feudal houses subject to the Zak'aryans. The founder of the house was Vače (pronounced vah-che), son of Sargis Vač utyan; Vače was described by the historian Levon Babayan as one of the "pillars" of Zak'arid rule. ${ }^{15}$ Like Tigran Honenc', Vače Vačutyan appeared as a princely historical figure in the early part of the thirteenth century, as the landscape of power shifted in the highlands. In return for valiant service in the wars of the Zak'aryans against the Seljuks, Vače was rewarded with the governance of territories and also with the title "prince of princes" (išxanac" išxan). Vače and his successors liberally deployed this honorific in dedicatory inscriptions on their building projects, including renovations and new constructions from the canyons of Alaverdi in the north to the southern Kasakh Valley. While Vače's most famous reconstruction projects are the monasteries of Hałpat and Sanahin (now registered as UNESCO World Heritage Sites), I am most interested in his - and his wife and childrens'-campaigns in the Kasakh Valley. The works of the Vačutyans in Aragatsotn include the rebuilding of early Christian (ca. fifth century) churches and the expansion of monastic endowments, including the sites of Astvacnkal, Tełer, Uši, Sałmosavank', and Hovhannavank'. Also probably included in this group is the church complex at Mravyan (Yełipatruš), located at the far eastern extent of the valley in the Tsaghkunyats foothills. Petrosyanc dated the later church (about a hundred meters west of the fifth-century chapel) to the early thirteenth century based on its formal similarity to Tełer. ${ }^{16}$ The reconstructive strategies of the Vačcutyans entailed making their mark on architectural monuments built by others, perhaps most famously illustrated at Sanahin and Hałpat; however, this strategy is also visible at the edge of the Kasakh Valley at the site of Tełenyac', where Vače and Mamaxatun recorded donations to the church endowed a few years earlier by another vassal of the Zak'arids, Vahram Č'avuš. ${ }^{17}$ This array of sites line the slopes of Aragats and the Tsaghkunyats and the canyon rim and floor of the Kasakh River, between the medieval towns of Ashtarak and Aparan (see maps 3 and 4 ).

The monumental constructions and epigraphic traces of the Vačutyans were dutifully recorded by Petrosyanc', producing a built geography of the broader district of the Kasakh Valley (Nig Aparan in Petrosyanc's pamphlet also includes the Tsaghkahovit Plain to the north of Mount Aragats). ${ }^{18}$ Petrosyanc's monumental geography is divided according to nearest village, a technique used by both Soviet and modern Armenian administrators to organize records of archaeological sites. In fact, Petrosyanc's pamphlet reads as an expanded version of the Monuments List maintained by the Ministry of Culture since the Soviet period. ${ }^{19}$ For each of 
the villages located along the rim and across the valley floor, he listed prehistoric (fortresses and "tombfields") and medieval sites. Remains of the medieval period are predominated by forts and churches, each of which is given a sketch plan along with their attached buildings: gavits (narthexes), side chapels, bell towers. These monumental structures stand out, the hard bones of medieval built landscape poking through the soil, marking the location of larger medieval places destroyed over time or buried beneath.

The lauded architectural exploits of the Vačutyans only end in the fourteenth century, once the territories of Armenia were reconfigured under Mongol, Persian, and Turkoman rule and the Vačutyans and their fellow dynasts "were removed from the stage of history." ${ }^{20}$ This idea, that landscape is built in the same register as history is written, has shaped archaeological approaches to the Middle Ages in Armenia, and has shaped what has been thought possible to say about what happened during this period. The idea also reinforces the elite authorship-focused understanding of practices that I framed as epigraphic world-building in the last chapter. Let me further complicate this relationship between authorship and the making of landscape, specifically in the context of my own construction of the Kasakh Valley through archaeological surveys.

\section{RECONSTRUCTING THE MEDIEVAL KASAKH}

THROUGH ARCHAEOLOGICAL SURVEY

In 2009 and 2010 I carried out exploratory survey in the southern upland section of the Kasakh Valley, between the modern villages of Kuchak and Apnagyugh. ${ }^{21}$ This work consisted of a combination of survey techniques, both "nonsystematic" exploration of villages and a series of systematic fieldwalking surveys across selected sections of the landscape. Nonsystematic or nodal survey is infrequently discussed by archaeologists, perhaps because it represents a point in research when we are least certain, and most dependent on the help and hospitality of local people. In other words, it is when archaeologists least feel like they are "discovering" something. This practice of survey requires driving or walking into a village and trying to locate buildings, complexes, or sometimes single stones through triangulations of management documents, publications, and the (usually) helpful advice of local passersby.

Fieldwalking survey is a particular archaeological technique, designed to pull patterns of past human activity out of the fields, forests, and hill slopes between highly visible archaeological sites like castles, churches, fortresses, or other standing architecture. In addition to being crucial for detecting features beyond the site (roads, terraces, check-dams, corrals), survey can be especially useful for locating small settlements, which through combinations of time, natural processes, and human practices become masked to easy view. In landscapes subject to erosionwhether from rain, runoff, or human activities like road building or plowing- 


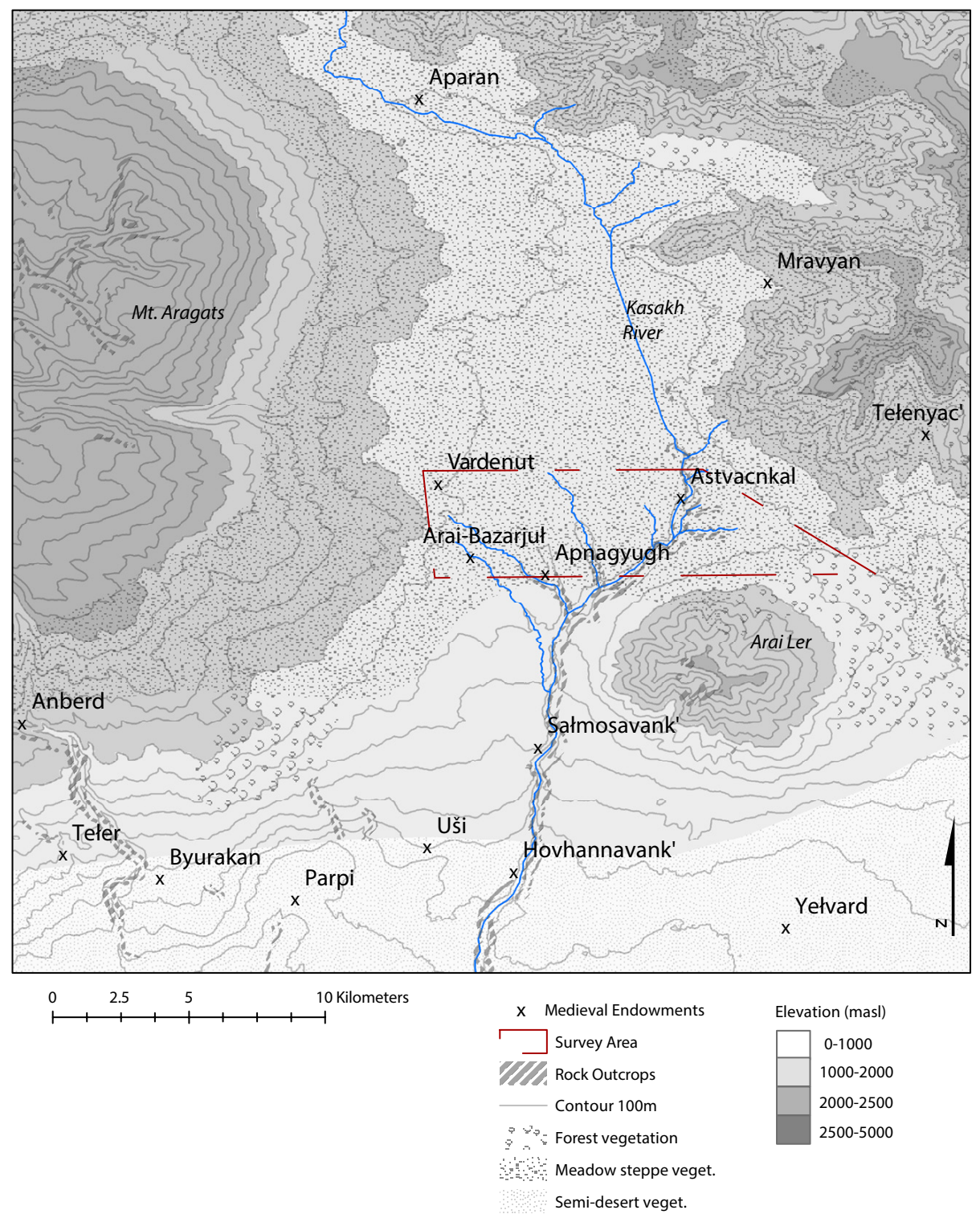

MAP 3. Contour map of the southern Kasakh Valley, with medieval places noted. Map created by the author.

archaeological artifacts, especially ceramic potsherds, can emerge and linger on the surface. A core task of archaeological survey is detecting patterns in the distribution of these artifacts, and in particular observing the higher densities which, in combination with other features, could indicate the presence of settlements or other sites beneath the soil. 
These two interrelated forms of survey produce different kinds of overlapping data, and different spatial understandings of a medieval landscape. The world created through archaeological survey and represented in survey reports is therefore always already a palimpsest of multiple worlds based on these evidences, each of which is a balance of collaborative memories, inferences, and intuitions.

Archaeological survey is carried out in the hope that these detected and interpreted distributions will provide a counterpoint to patterns of visible monumentality or place names extracted from history or epigraphy-that they will ultimately help to tell a different or at least complementary story about life, and time, in a place. The central goal of my own systematic surveys was to generate material data about the Kasakh as a place in the high Middle Ages, to fill in the blanks between the sites that were known to archaeologists and listed in official documentation like the Soviet passport system or the Monuments List. The focus of our fieldwalking survey was therefore not discovery of "new" sites so much as a deliberate attempt to understand the social and temporal relationships between occupied places in a mountain landscape. The 2010 season of the Kasakh Valley survey covered ten square kilometers of the valley, recorded coordinate data, images, and observations for a range of site types, and collected more than twelve hundred ceramic sherds as well as lithics and other artifacts.

The ceramics collected on the survey were divided into two broad categories; those that had complete profiles and were of a size sufficient to analyze were selected out and assessed for attributes: color, fabric, production aspects, decoration. Part of the intent behind ceramic systematization was to date as many of the sherds found on the survey as possible, and thereby to provide temporal information for the human activity indicated by ruined settlements, cemeteries, and so on that we recorded in the sector. Using ceramic artifacts as a chronological indicator means that past human activity is perceived through the lens of ceramic production, use and deposition; this in turn means that the activities dated and spatially assessed by the following analysis are related to the use and reuse of certain kinds of storage, transport, cooking and eating vessels, and this suite of ceramic-based activities is used as an analytic stand-in for medieval daily life in general.

Ceramic materials were identified as falling within one of six chronological ranges, ${ }^{22}$ based on synthesized information about medieval ceramic chronology in Armenia. A few key ware types were determined to be diagnostic of certain periods: for instance, fine, high-fired white-slipped white ware and white-slipped red ware were indicative of Medieval I, while red-slipped red ware cooking pots and table wares were diagnostic of High Medieval I. A few glazed examples fell into the High Medieval I category, primarily green-on-white monochrome sgraffito wares; the transition to the High Medieval II period is marked by decorated forms such as piecrust-applique decorated red ware bowls as well as glazed fritwares. A critical analytical issue is related both to the ceramic sample size from the survey and to the state of knowledge of medieval plainware (unglazed ceramics) chronology in Armenia, in that many formal plainware categories seem to cut across established 
chronological divisions (which have traditionally been built from typologies of exclusively decorated fineware forms).

Mapping the distribution and relative density of these ceramic finds shows that the recovery of ceramic materials within the survey area was not random, but significantly $(p<.05)$ clustered around particular locales. Specifically, instances of clustering occurred around the high medieval Vardenut castle, in the canyon bottom at Apnagyugh, and on the edge of the valley south of Arai village at Ambroyi. I spatially plotted the results of the chronological ceramics analysis in an ArcMap GIS, yielding a series of map outputs which demonstrate both concentrations of ceramic deposit suggestive of occupation, as well as shifts in landscape occupation through time by people making and using pottery. These maps showed that settlement and activity was not randomly distributed, and that densities of activity shifted to different areas over time. In the High Medieval period, sites tend to cluster in a few location types. Rather than a consistent distribution of remains across the valley, materials were concentrated in two primary areas. The first of these areas consisted of the wide riverbanks where the Kasakh River and its primary tributary cut deeper into canyons. The second area of denser occupation is the low shoulder of Mount Aragats, in the undulations carved by streams running off the mountain between basaltic outcrops. We also recorded an area of high sherd density (dated later, into the Early Modern period) on the eastern rim of the Kasakh canyon, on the slopes of Arai Ler north of a modern dacha village. Settlement during the medieval period was not (according to the ceramic data) located in the middle of the exposed Kasakh Valley, but rather demonstrated a regard for relatively sheltered, well-watered sites. Many contemporary villages persist on or near the sites of medieval settlements, though the patterns of abandonment and occupation also indicate shifts in land use and social relationships since the medieval period-specifically, into regional administrative centers like Kuchak and Aparan, nearer to the modern highway connecting Yerevan with the north.

Patterns in ceramic distribution assessed over time suggest that sites which were occupied earlier in the medieval period continued in use in the High Medieval period. Furthermore, diachronic shifts in ceramic distributions and quantities indicate an increase in activity during the High Medieval period, concentrated on in the central and western sectors of the survey quadrant. The chronologically differentiated distributions demonstrate that Early Medieval and Medieval I material was more sparsely and widely distributed over eastern and western areas of the survey sector. The High Medieval period into the Early Modern period shows, in contrast, a strong concentration of material in the western sector, around Vardenut and Ambroyi settlements, as well as near the site of Apnagyugh. This distribution suggests a link between the settlement of villagers in the western section of the valley and the construction projects of the Vačutyan princes in the thirteenth century-many of which were supported by personnel and materials from those villages. The patterns of the data also suggest that currently isolated clusters of contemporary material such as Vardenut, Ambroyi and Apnagyugh 


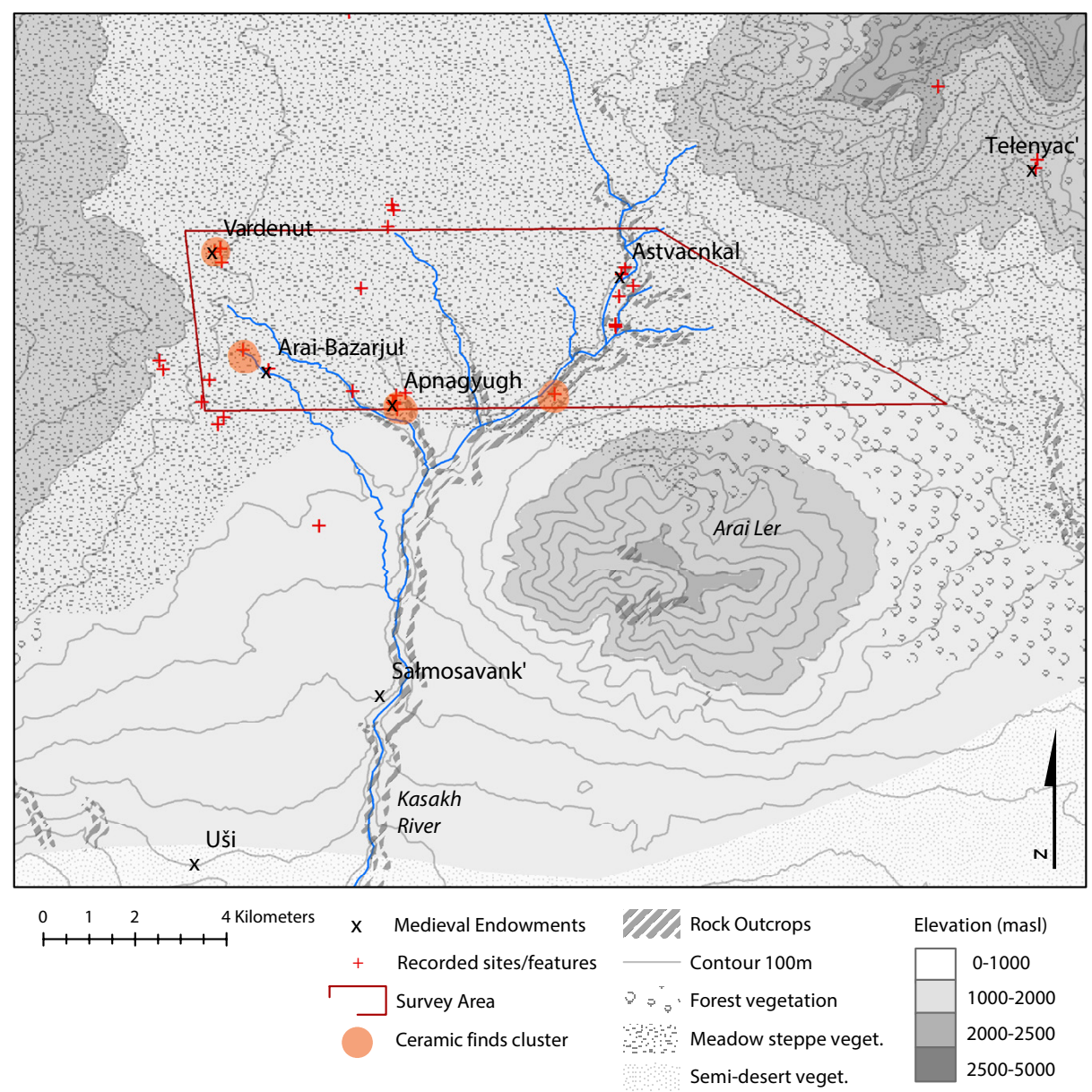

MAP 4. A closer view of the survey area, showing high-high sherd cluster points (orange). These indicate points of high density within the collection of ceramic materials within the surveyed area. Map created by the author.

were during the medieval period a more continuous area of settlement, cultivation, husbandry, church, cemetery, and caravanserai. This is a critical thing to remember: that inhabitants of the Kasakh and travelers through it, like their modern counterparts, lived in a knit-together landscape in which ruined forts, fields of mounds, villages, bridges, and churches were all legible parts of a cohesive world. And ceramic scatters in themselves do not show us straightforward evidence for a whole range of medieval daily life, including herding, hunting, and, of course, travel. In fact, recent continuing research in the Kasakh by my friends and colleagues has recorded medieval and early modern (thirteenth through nineteenth centuries) settlements high on the slopes of Mount Aragats; ${ }^{23}$ future material and spatial analysis may further expand the medieval world in these valleys. 
The relationship between patches of sherd density and the more widely ranging practices of medieval life raises an issue of archaeological evidence, and of the processes by which patterns on the ground are "read" as patterns of life in the past. This legibility of landscape is summed up in the frequently invoked archaeological metaphor of the palimpsest: landscapes which have been inhabited and reinhabited through time are thought of as medieval vellum manuscript pages that have been written on, scraped, and rewritten, resulting in a layering of texts, traces, and erasures. ${ }^{24}$ To imagine archaeological landscapes as palimpsests requires us to think about practices of reuse that alter or destroy previous patterns even as they produce new ones. This is especially relevant to the material patterns recovered in the Kasakh Valley which, like many agrarian zones of the South Caucasus, were aggressively transformed during the Soviet era in a process called meliorizatsiya or landscape amelioration. The drastic results of amelioration, combined with the heavy alluviation of such damaged mountain surfaces, frustrates techniques of archaeological survey developed in the plowed fields of the Mediterranean. ${ }^{25}$ We encountered the effects of amelioration in the Kasakh as strange patterns of ceramic distribution and stark sculpted contours of hillsides and fields. As we recorded fields which had been scraped bare, leaving a curving berm of rubble and medieval artifacts like an arched eyebrow on the edge, we learned firsthand how to interpret the history of a violently altered landscape. My survey record of the medieval Kasakh thus includes "ghost sites," such as a village of unknown size that would have been located south of Hartavan near the edge of the river gorge. Luckily, the high medieval village of Ambroyi-Hin Bazarjut, located south of the modern village of Arai-Bazarjuł, was only partially erased by ameliorations. A section of preserved, buried rooms remains from an original village which would have probably extended as far as the medieval road and the karavanatun or caravan inn.

\section{From Surface Assemblage to Assembled Medieval World}

This review of archaeological survey provides a complementary narrative to the images of the Kasakh Valley presented in textual sources like those written by T'oramanyan and Petrosyanc'. The village sites and concentrations of material culture demonstrate the world of activity and daily life which was the necessary context for practices of architectural and epigraphic world building undertaken by powerful Armenians during the high Middle Ages. In the medieval period, the southern Kasakh Valley was located two- or three-days' journey east and north from Ani and participated in the shared worlds of imagined space and monumental spacetime laid out in the last chapter. As discussed in that chapter, Tigran Honenc' of Ani was only one of a broad network of princes, princesses, emirs, and other officials in the Caucasus, Anatolia, and the eastern Mediterranean connected by imaginaries of power and social prowess, and by the shared cultural spacetimes of the Silk Road world. For the rest of this chapter I am going to focus on one dynastic house or family of these Armenian princely men and women, the Vačutyans. As discussed above, the Vačutyans loom large in the architectural and historical 


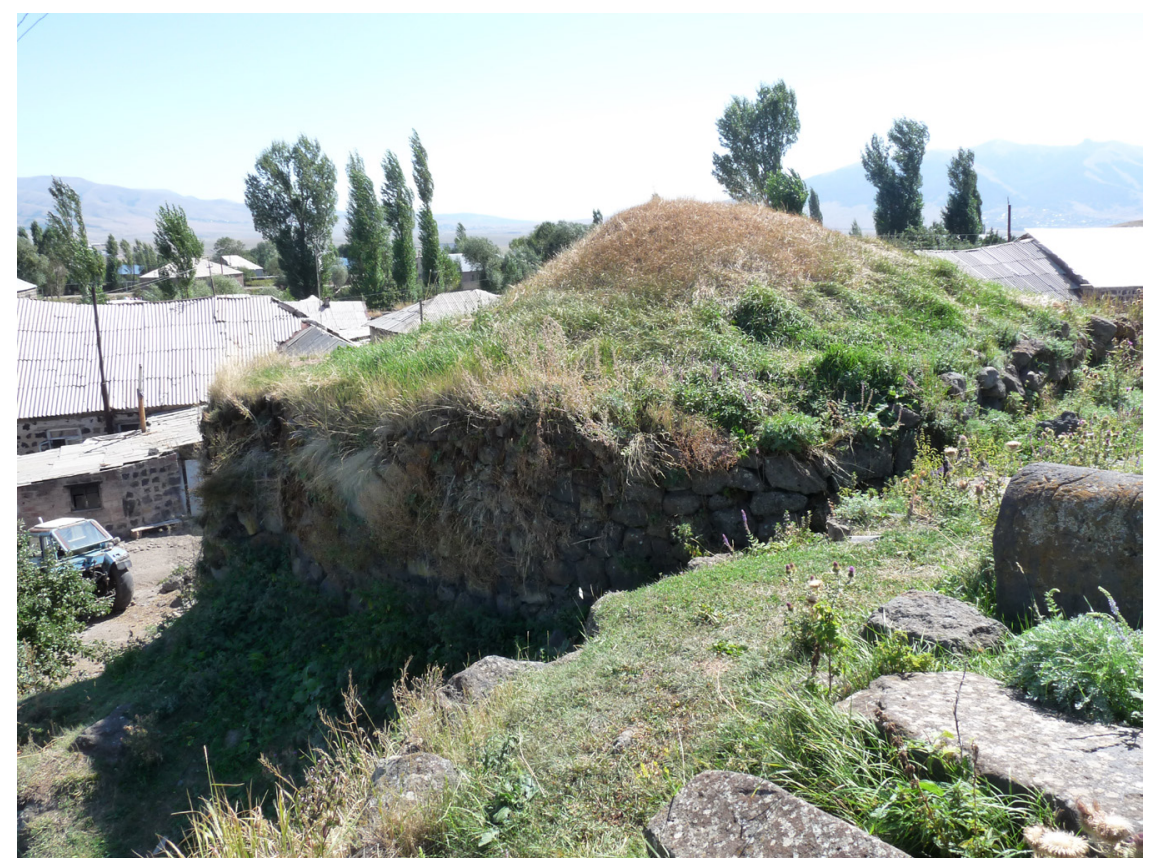

FIGURE 9. The remaining bastion of the Vačutyan castle of Vardenik (now called Vardenut), photographed from atop the wall. Note the later medieval gravestones, and Arai Ler in the righthand background. Photo by the author.

memory of Aragatsotn, due to their prolific (re)construction projects and to the number of their dedicatory inscriptions. Traveling up the road from Ashtarak, the pass to the highlands is effectively overseen by the Vačutyan endowments of Hovhannavank' and Sałmosavank', both perched on the rim of the at-that-point dramatically encanyoned Kasakh River. The Vačutyans' construction projects were concerned with the gaze of travelers approaching the Kasakh Valley; their standing buildings are notable for their exceptional views over mountains and plains as much as for their commanding presence. ${ }^{26}$ During the medieval period, the drum-shaped domes of the Vačutyan endowments would have punctuated the horizon as travelers passed up the valley, mirroring the grandeur of the peaks of Ararat and Arai Ler. Notably, as discussed above, these buildings frequently incorporated renovations of earlier structures which were multiple centuries old and perhaps ruined, but still culturally meaningful, at the opening of the thirteenth century. The Vač utyans' buildings therefore gazed across time as well as space, and were complex, compound spacetimes in themselves (see fig. 9).

One of Vače Vačutyan's first known renovation projects in the Kasahh Valley was the reconstruction of a chapel and an endowment to the monastery of Uši, located on the southeastern shoulder of Mount Aragats. Uši is a shrine as well as 
a monastery, centered on the fourth-century relics of St. Sarkis (known as Sourb Sargis Zoravar or St. Sarkis the General), contained within a small chapel to the north of the main church. A martyr to Sasanian persecution, the presence of Sarkis's saintly bones situates Uši within the heroic spacetime of early Christianity. In his 1203 renovation inscription on the Uši chapel, Vače Vačutyan described his pious donation to the monastery: "I Vače Vačcutyan, Prince of Princes, Son of Sargis, Governor of this land, by the edict of Ivane and Zak'are, adorned this church with the pyx (for) holy communion of silver and donated much other property, ${ }^{27}$ including the garden of Dapaghent in Yerevan bought for my money (dramagin) and established a mass to be served regularly on Palm Sunday in all the churches to the glory of God and for the salvation of my soul. Dated 652 (1203)." 28 Note how, like Tigran Honenc' did in the last chapter, Vače begins his inscription by naming himself (and his father Sargis) and situating himself in relations of worldly power with his lords, Ivane and Zak'are Zak'aryan. Even though this is a much shorter inscription than that of Honenc', Vače still undertakes the same strategy of assembling, as he brings together places and practices (gardens, masses) as well as objects. Again like Honenc', Vače makes explicit the fact that he has purchased his donations with cash; in other words, he is grafting his prowess as a merchant onto his performance as a donor. This tactic works to circumscribe the world of trade relationships into the heroic spacetime of the Uši martyrion.

This practice of place-making is further exemplified by the Vač'utyans' donation invocations at the monastery complexes they renovated throughout their purchased province of Nig. In 1211 Vač́e built "at great cost" a gavit for the eleventhcentury monastery of Sanahin, which is located on a rim of the Lori canyon to the northeast of the Kasakh Valley. ${ }^{29}$ In two inscriptions on the walls of the gavit, Vače describes in this increasingly familiar language how he donated not only his "oathspace" (uxt: generally covenant but in this case the gavit or assembly hall) itself, but also the instruments (gold-bound gospels) for liturgy to be said every Saturday and Sunday in the name of himself and his wife, Mamaxatun. ${ }^{30}$ The inscriptions denote Vače as the servant of the Zak'arids, and also invoke his father Sargis as well as his privileged relationship with the elders of the church, designated to intercede on behalf of his soul.

The epigraphic landscape of the Uši and Sanahin inscriptions overlaps with the world circumscribed in the inscription commemorating the Vačutyan's renovations at the monasteries of Sałmosavank' and Hovhannavank', situated on the rim of the Kasakh River gorge. According to tradition, the basilica church at Hovhannavank' was built in the fourth century by Gregory the Illuminator to house the relics of John the Baptist; the single-naved structure on the site is generally dated to the fifth century. ${ }^{31}$ In 1217 Vače and Mamaxatun endowed a cruciform church attached to the earlier basilica, which they had rebuilt. Both churches were decorated with relief carvings of birds and intricate panels of geometric decoration; the bema of the main church especially is faced with a beautiful tracery of interlaced five-pointed 
stars (a similar pattern adorns the tympanum of the gavit at Sałmosavank'). Vače's donation inscription on the north wall of the main church reads:

666 (1217). Created by the grace of God, in the established region, enlightened by the church, of Ayrarat in the hands of the two kin brothers Zak'aria and Ivane, and by the just-born heirs of those same Šahnšah and Avag, I Vače prince of princes, son of Sargis Vačutyan, beloved of him, with great honor and for my faithful service am I enabled as warden of the district. In union I am coupled together with my Mamaxatun for the holy [uxt/oath] of our St. Hovhannes, in laying a foundation with gifts and offerings and have built an illustrious new-built purgatorium. And may the leaders within the holy [oath] be sure in every month to say a Mass to Christ in my name, for the festival of Lazarus in every church, new and old. And for the pious Mamaxatun Mass shall be said to Christ in the old and new churches, until the coming of the Son of God. And he who shall not do so, let Christ judge him, Amen. ${ }^{32}$

The choice of words in these inscriptions is not incidental, but rather consciously refers to the pious naxarar traditions that the Vačcutyans were attempting to renovate and reinhabit, even as they renovated buildings from earlier periods in Armenia's Christian history and built them into new topographies of power. Christina Maranci has shown that the tradition of referring to an endowed church as an "oath" dates back to the seventh century in Armenia. ${ }^{33}$ Maranci's approach to medieval church building is thus oriented around this idea of the church as an oath or covenant-in-stone, a way of tying the spatial down with the power of the textual. In referring back to the traditional concept of church-as-covenant, the Vačutyans were clearly staking a claim to the power embodied in the built heritage of the pre-Seljuk Armenian landscape. The idea of a building as an oath directly evokes the spacetime compressions proposed by Munn as inherent in hospitality or gift giving. The inscribed church extends the promise of good governance made by the donor forward in time, rooted in built space. But I am also interested in how the Vačutyans-and their contemporaries-incorporated this text into a political assemblage along with human bodies (their own and their subjects', the relic body parts of saints), and scales of space and time ranging from everyday life, to season liturgical ritual, to the large scale of long-distance trade relationships. Even though they made extensive use of inscriptions, their technique of circumscribing the local in the large-scale extended beyond the mode of textuality. These inscriptions serve as a narrative practice of world-making that was undertaken in spacetime and material culture as well as in words carved into church walls.

Like Tigran Honenc', the Vačutyans performed a world-assembling in their donation inscriptions, which was mirrored in their purchase and dedication of places, goods, and practices within the Kasakh Valley. For instance, in 1244 Vače's son K'urd and his wife, Xorišah, dedicated a kathotical church abutting the recently restored fifth-century basilica at Astvacnkal (discussed above), located on the floor of the Kasakh River gorge. The spaces endowed at Astvacnkal are noteworthy in their design. As shown in figure 10, the vaulted ceiling of the gavit (now collapsed) 
was wrought in geometrical muqarnas, making Astvacnkal a primary example of a pan-Anatolian style of architecture which united Islamic and Christian spaces in the thirteenth century. ${ }^{34} \mathrm{~K}$ urd and Xorišah's dedicatory inscription is located above a doorway to the south side of the bema, the same location as the textilestyle decoration in St. Gregory's cathedral that I discussed in the previous chapter (indeed, T'oros T'oramanyan described Astvacnkal as modeled on the example of St Gregory's church). In this inscription, K'urd describes the couple's gifts to Astvacnkal: "I K'urd, prince of princes, son of the great Vač'e, and my wife Xorišah, daughter of Marzpan, built this our Holy Katolike in memory of our souls. We have decorated it with every ornament and gave as well the garden bought by us in Parpi, one plot of uncultivated land in Ošakan, one garden in Karbi, ${ }^{35}$ a commoner servant [šinakan], and three hostels [votjatun], and to the chamber of the Episcopos a cross and book, in the year 693 (1244)."36

Written a few decades later, K'urd's dedication calls back to Tigran Honenc's inscription on the other side of Mount Aragats, as well as the epigraphic practices of his parents. The Astvacnkal inscription weaves together a plurality of spacetimes in the service of K'urd and Xorišah's memory: the produce of gardens and the tilling of new land, as well as the labor of servants and specific costly objects to be used in ritual practices. Among the assemblage would also possibly have been potent human remains; T'oramanyan hypothesized (drawing on Šahxatunyan) that the original church renovated by the Vačutyans was built as a shrine to St. Hakop and contained his relics. ${ }^{37}$ Recall back to the nested, embodied spacetimes built into the architecture of medieval churches in Armenia discussed in the last chapter. By exhuming these relics and reburying them within the new church, K'urd and Xorišah incorporated the powerful body of the saint into their own "body," joining the world of their pious memory, and that of their lineage, with the fame of St. Hakob. The church would continue to embody the assembled realms of K'urd and Xorišah's power-even as the floor of the gavit is lined with the accumulated buried bodies of their medieval kin and subjects.

A decade later K'urd and Xorišah recorded their renovations and donations of new facilities (a belltower and a scriptorium, respectively) to the monasteries of Sałmosavank' and Hovhannavank', adding their names to the walls inscribed by K'urd's parents. ${ }^{38}$ Their matching inscriptions-dated 1250 at Hovhannavank and 1255 at Sałmosavank'-further orient their embodied spacetime within even broader 'scapes of Silk Road history and temporality. In particular, these texts give us a glimpse at the ways the Vačutyans worked to house the world of the Kasakh Valley within a world that had been knocked about its axis by the Mongol invasions. In their preambles, the inscriptions relate how, having proved themselves worthy to their new rulers, K'urd and Xorišah set about rebuilding sections of the churches built by Vače and Mamaxatun that had been ruined during the conquest. Interestingly, the inscriptions invoke these new rulers not by name or as Mongols, but as "the world-conquering army of Archers" (ašxarhakal zavracn netołac). ${ }^{39}$ 
This phrase calls us back the epistemological spacetimes, or worlds, within which Christian people in Armenia and Europe made sense of the Mongol invasions. As Zaroui Pogossian has argued, for more than a decade into the Mongol conquest of the Caucasus, earlier, apocalyptic narratives of a "Nation of Archers" locked behind mountains by Alexander mediated people's experience of the invasion. ${ }^{40} \mathrm{I}$ am fascinated by K'urd and Xorišah's choice of words in their inscriptions, even as I hesitate to read too much into them. Their endowment inscription at Sałmosavank' commemorated the new space to their sons and daughter, ${ }^{41}$ and extended the fame of their built world into the future that those children embodied. This shows the practical, narrative work of mending political cosmologies so as to stretch beyond the invasion that their contemporary historian Kirakos Ganjakec'i understood as the "end of time."

Through their epigraphic evocation of a genealogical future, the Vačutyans tied down a stable axis for their own world even as the wider world shifted. These inscription practices show the wide variety of spaces-villages, gardens, inns, stables, as well as sacral and monastic spaces-which were participant in that world, and in political life in the medieval Kasakh Valley. The breadth of this landscape argues against a narrow historical or archaeological focus on text as the exclusive domain of power, or on "elite spaces" (cities, forts, monasteries) as the exclusive loci of social (re)production. Quite the opposite: medieval Armenian princes were concerned with the extraurban landscapes of the highlands, as well as the wider world of Silk Road travel and trade. The scope of their political care was also expansive in temporal terms. Vačce and Mamaxatun, K'urd and Xorišah, and their successors not only built new monuments to their piety and political power, but also worked the historical landscape within a spatiotemporal assemblage of built, perceived, and lived places to situate themselves in a world of traditional values-the conjoined "new and old" of their inscribed texts. These values themselves were legible within the bounds of medieval Armenian institutions: sovereignty, religious authority, personal piety, and hospitality.

The world inscribed-or circumscribed-within the epigraphic space created by the Vačutyans on the walls of buildings combines in interesting ways with the understanding of landscape constructed through my survey. The reconstruction of churches and the layering of inscriptions and reiteration of donations constructed a palimpsest of a different scale than that of village houses and distributions of pottery sherds-and different again from the scale of the landscape as written by T'oramanyan and Petrosyanc'. But these scales overlap and intersect. The span of space invoked, for instance, by the Astvacnkal inscription encloses fields and gardens on the southern shoulder of Mount Aragats, between Astvacnkal and the monastery of Tełer where Mamaxatun and Vač'e were buried; some of these sites are visible on map 3. The inscriptions also only sketchily refer to the lives of other inhabitants of the valley, or their everyday lives. The Hovhannavank' inscription calls upon the labor of the monastic clergy, whose liturgical calendar is augmented 
with prayers and masses in the Vačutyans' memory. The Astvacnkal inscription invokes a servant as well as the maintenance work contained in (and sustaining) three hostels. Turning from the epigraphy to the surveyed landscape, I can only speculate on which village the servant lived in, or where the hostels were located. The 2010 survey recorded ceramics and architectural remains in the canyon south of the monastery, in addition to the remains of the village that actually surrounded the church described above. Perhaps the canyon settlements included resting places for travelers and visitors to the monastery to stay close by, similar to the guest house at Noravank' (discussed in the next chapter). Working back and forth across these datasets I frequently reflect on the intersecting processes of erasure-whether epigraphic elision (and erosion) or large-scale landscape "amelioration"-which impede our perceptions of the active, busy landscapes of which the Armenian churches were but a part.

At the same time, the evidence we do have lets us think in multiscalar ways about those busy, dwelled-in landscapes, by considering the material practices that made and sustained those worlds. The survey data and inscriptions reiterate that many of the construction projects undertaken in the Kasakh Valley by the Vačutyans were actually reconstruction projects, emphasizing the interpretive and contingent aspect of landscape production stressed by John Barrett: "the construction of monuments is always an interpretation of a pre-existing world." 42 The people who lived in the Kasakh Valley in villages like Apnagyugh, Vardenut, and Ambroyi dwelled in a landscape that was not only in-process from their own agropastoral activities, but was also already full of the remains of past human actions. The practice of survey challenges archaeologists to simultaneously parse landscape into "signatures" and to reflect on how that landscape was dwelt within by people in the past. For instance, future excavations of the Bronze Age fortresses above Arai-Bazarjuł and Vardenut might demonstrate the occupation and use of those sites by people in the Middle Ages, as was the case at the Bronze and Iron Age site of Tsaghkahovit to the north. ${ }^{43}$ The traces of recent pastoral camps along the slopes of Aragats and the Tsaghkunyats provoke me to reflect on how these upland zones would have been utilized by medieval people in ways that left few enduring traces, even as they supported dairying and textile production in the valley villages and monastic centers. Rather than a static "local" landscape, the Kasakh itself would have been tied together by seasonal, habitual, and everyday mobilities. Some of these are attested to in the inscriptions described above: for instance, the donations of gardens and fields in Ošakan, Karbi, and Parpi to Astvacnkal suggest the movement of produce and paid rent revenues from the southeastern slope of Aragats to the monastery in the canyon. The donatory inscription at Uši indicates that the monastery did not merely physically overlook the Ararat plain; rather, it drew rents up from the gardens around Yerevan. Our ceramic datasets collected on survey suggest the movement of pottery within the valley, from village to village, as well as from larger production sites outside the valley (see 
chapters 5 and 6 for more discussion of this). Overlapping these skeins of data at various scales, stretched in different directions, I imagine the Kasakh Valley as more than a feudal holding or a place passed by the traffic of a minor capillary of the Silk Road. Combining material, spatial, and epigraphic data in place evokes the business of everyday medieval life, and also the multiplicity of projects, of little and not-so-little worlds. The realities of donated spaces constructed through epigraphic practice, and the world of political alliance, patronage, and aspirational power, were co-constructed with (and thus dependent on) the overlapping worlds of farm work, seasonal rents, holidays, and Masses, as well as with the mobilities of travelers and trade through the valley. The trek up the valley made by Het'um and described in the introduction was a short section of a longer journey for him, but also a brief window into a dynamic local world that carried on after he had passed over the horizon.

The next chapters will explore how the imagining of Armenia's place within a broader Silk Road world was undertaken everyday by people in their material lives, as they moved within the spaces endowed by princes like Vače Vač utyan but also as they sat and ate, and shared food, goods, and stories with passersby on the mountain highways. In order to do this, I will spend some time in a space where the broader world of the medieval Silk Road and the everyday, "local" worlds of the Kasakh encounter one another. According to the inscription recorded by T'oramanyan but now lost, in the year 1213 Vač́e Vačcutyan (perhaps in partnership with Mamaxatun) endowed a karavanatun in the Kasakh Valley. This caravan house or highway inn was strategically located near both the highway north through the highlands from Yerevan toward Tbilisi, and the Vačutyan castle at Vardenik (Vardenut). The ruins of the karavanatun still stand on a raised hill in the middle of a field, south of a modern village which is named Arai on signs and maps, but whose inhabitants know it as Bazarjut, the marketplace. 